\title{
Conversion of Indigenous People in the Colonial Andes: Politics and Historical Understanding
}

Historical and anthropological approaches to conversion in the Andes have often been influenced by political attitudes toward the effects of Spanish colonialism, both in the past and in contemporary society. The importance of religious conversion in the colonization of the Andean region and the crucial place religion has in its culture explain the continued interest in the subject. However, conversion has not been explicitly discussed as a conceptual problem. The absence of a discussion does not mean that scholars have pursued their research without a prior idea of what is conversion, even in the most descriptive of accounts. In reviewing the literature, it is difficult to identify proper debates.

Political and ideological issues often interfere in attempts to elucidate this and other concepts. Students, academics, and the general public often expect from the historian a straightforward statement about Spanish colonialism in the Andes as a whole. Certainly, the acts of invasion, different forms of extermination, enslavement, spoliation and the validation of varied systems of social discrimination distinctive of colonialism are unacceptable. The assumption that such events took place so long ago that they are not worth a discussion, also seems wrong. The uncertainties and complexities involving the study of colonialism and the difficulty to explain its subtleties and contradictions are frequently met with misunderstanding. I am neither suggesting that we historians should entirely dissociate our research from political concerns, nor advising that we should abstain from taking part of debates about the political significance of the themes we study. However, understanding a historical problem and elucidating the concepts we use that allow comprehension require staying alert of the dualisms and quick conclusions politics often steer us to.

The situation I have just described has of course an explanation, and an important one. The deep social inequalities and injustices that still mire Andean societies are key issues of concern. However, the reasons for today's tribulations are often solely attributed to Spanish colonialism. Issues of identity in a region as culturally diverse as the Andes are also perceived primarily through the prism of a simplistic assessment of the colonial past. This interpretation, both uncritically and strongly embraced by many, is a sort of popular belief, the attitude with which many Andeans try to make sense of a complicated, painful past and a no less troublesome present. Among wide sectors of academia the idea of reducing their countries' present malaises to Spanish colonialism is quite extended. While it is true that some of the deepest roots of domination in regions like the Andes date back to Spanish colonialism, the suggestion that the present can be chiefly explained by the Spanish colonial past has bred a refusal to investigate it in its most nuanced and uncomfortable details. ${ }^{1}$ The oversimplification of history has also delayed or even prevented the shaping of a critical approach toward the legacy of Independence from Spain and the following two centuries of republican rule.

A study of religious conversion in the early modern Atlantic world published recently in this same journal $^{2}$ discusses the subject as a conceptual problem and examines a range of alternative terms to better describe it. Interestingly, no political issues are mentioned in the study. In contrast, and for the reasons previously mentioned, historians of the Andes have not dealt with the concept in such fashion. Studies of religious conversion contain ideas of what this phenomenon involves, even if they are not always expounded. The historical literature shows ideas about conversion are manifested in the title of a book or an article, in the methodological approach used, in the selection of sources and the perspective taken. A few authors, especially the earliest, were keen to provide favorable views of the impact of Spanish rule on Andean culture, while others opted to condemn colonialism. Still others have prioritized an analytical approach to the subject, and are cautious about making sweeping statements.

This essay studies changing understandings of conversion in Andean historiography. The review of the literature goes as far back to the time when conversion was seen as a civilizing endeavor. The 
essay then discusses the widely accepted ideas of syncretism and resistance to investigate conversion, and then moves on to the study of conversion as a crucial theme in Andean cultural history and a related viewpoint that sees conversion as world-building. Throughout, the essay examines how politics appear to define different approaches to this phenomenon.

\section{From conversion as civilizing endeavor to resistance and syncretism}

Studies aiming to cover a wide range of themes involving religious change in the context of Spanish colonization appeared within a short time span in the mid-twentieth century. An institutional approach was their trademark, something not surprising since the topic, conceived as Church History, was dominated by ecclesiastical authors depicting the role of the Catholic Church under the most positive of lights. These studies were highly descriptive, relying on an impressive repertory of documents, many of them not easily available at the time. ${ }^{3}$ Authors often published substantial collections of the primary sources used, either independently or as complements to their works. Although to readers new to Andean historiography these works would give the impression of obsolescence, their influence on historians of later generations has been so important that it has to be acknowledged. These works often provided a useful chronological account and descriptions of the institutions, individuals and legislation laying out the foundations of the missionary enterprise, especially from the period immediately following the conquest (1532) up to the late seventeenth century. One of the most important works, History of the Church in Peru, ${ }^{4}$ suggests that the Catholic Church existed as a supranational institution with a defined profile and a plan to be applied in the countries where it set roots. It was a universal community to which peoples and nations were gradually incorporated. In this study, the evangelized have chiefly a passive role, and are depicted as slow to understand or accept the message missionaries brought to them. Conversion was portrayed as a result of the Spanish missionaries' divine calling, where the converted are above all the recipients of the Christian faith and little more.

The same year Vargas Ugarte's book appeared, Spanish historian Fernando de Armas Medina's monumental Cristianización del Perú came out from the press in Seville. ${ }^{5}$ Although imbued of the mood then prevalent in Spain under Franco, ${ }^{6}$ of complete adherence to the Catholic Church and in praise of its civilizing role, this book has useful features. Armas' view was far more informed, dynamic and analytical than other contemporary studies. Armas was not only satisfied with publishing his archival findings, which he meticulously cited throughout his book, but also reflected upon their contents making interesting connections between, for example, Spanish and papal and Spanish and Andean politics, something no one else was doing at the time and few attempted to make in the following decades. Armas presented conversion as both shifting and problematic: indigenous Andeans could sincerely convert to Christianity, for example as a result of an inspiring Jesuit mission, but return to their previous practices if no conditions for continuity existed or reinforcement was provided. To an extent, Armas acknowledged that converts or potential converts did have agency and were thus capable to produce their own doctrinal or ritual interpretations. Importantly, the Catholic Church is not portrayed as a monolith. This study had the potential to open new windows into the understanding of conversion but its most interesting contributions were not taken further by other authors. Clearly, the intellectual atmosphere of the 1950s was inauspicious. A book published in Madrid in 1960 by the Franciscan Pedro Borges, ${ }^{7}$ a study of the methods missionaries employed to convert the indigenous population of Spanish America, focused exclusively on the sixteenth century. Although arguing that psychology had a crucial role on conversion, Borges made no use of psychological theory. The archival work behind this study is impressive. The aim of covering the whole of the Spanish Indies, and numerous and complex actors, was an enormous task. Borges shared with Vargas Ugarte the view that as a supranational institution, the Catholic Church applied the same methods and policies throughout the Spanish American possessions without significant local constrains. The idea of a divine calling also permeated his understanding of the missionary endeavor, and the eminently passive role and backwardness of the evangelized is a clear assumption throughout the book. Borges made a serious attempt to organize the enormous amount of materials gathered. Each chapter corresponds to a classification of the wide range of methods of religious indoctrination Spanish 
missionaries put into practice: persuasion and repression, art and preaching, political alliances and formal education, and so on. In this sense the study is certainly professional and academic. However, it is marred by its deep social conservatism, which accounts for the author's overall uncritical approach to its subject.

For about the following ten years no major work was produced on the subject. The view of conversion as a duty following a divine call, a civilizing endeavor exerted upon an indigenous mass that had little or no agency and not much to contribute to the church but their labour and material resources, prevailed. The Catholic Church was an institution whose methods and authorities were not to be challenged, and religion was a natural human instinct or disposition the Church had to steer in the right direction.

In the early 1970s Pierre Duviols brought about a significant shift to the study of Andean religious change. His book furnished a fresh interpretation of Andean colonial history that run against the prevailing pro-Spanish approach to conquest and colonization, considering this period instead as a long-term, many-layered endeavor to eradicate Andean religion. ${ }^{8}$ Using a rich archive formed of the records produced during the so called 'extirpation campaigns' ran in the Lima diocese in the seventeenth century, Duviols aimed at studying the intellectual and political antecedents of religious repression and its main agents. ${ }^{9}$ Thus, Duviols looked at Spanish attitudes about nonChristians, investigated several aspects of Spanish Catholicism like attitudes toward dissent, and analyzed the many documents produced by both ecclesiastical and civil authorities in Peru revealing their attempts to make sense of, and proceed to, undermine the religious ideas and practices they encountered throughout the Andes. Duviols took part of a vigorous intellectual trend in France that applied anthropological methods to historical records to investigate and interpret religions and other cultural phenomena and understand their social meaning. Duviols' experience as Andean scholar was strongly influenced by his collaboration with Peruvian intellectuals committed to the investigation of indigenous culture and critical of the then prevailing ideas about Spain's role in the Americas. ${ }^{10}$ Duviols saw conversion in the Andes as a confrontational, multifaceted endeavor that was met with indigenous resistance. Ultimately, the author's assessment is that conversion to Christianity in the Andes was a failure, as the Spanish were unable to neither shatter indigenous religious practices entirely nor identify how Andean religions continued to survive although disguised. ${ }^{11}$

The arguments Duviols advanced in his 1971 book had the potential to get scholars thinking about what had changed in Andean culture, and particularly religion, during the colonial period. These issues gained importance in the following years although there was no discussion and publications were sparse. The work by the late Manuel Marzal, represented an important landmark. Marzal's book, La transformación religiosa peruana, has been deeply influential within and outside academia. ${ }^{12}$ Perhaps more than any other author, he was the most vigorous supporter of the idea of syncretism. He conceived religious transformation as proceeding in stages, with periods in which-especially during the earliest years - the Catholic church was active and even effective, to the point that by the late seventeenth century Catholicism had taken a firm grip. The end of Spanish colonial rule brought a sharp fall in the number of clergy and a regression of Catholicism amongst the peasant population, which continued up to the following century, Marzal suggests. Catholicism, as practiced by Peruvian peasants, involves an acknowledgment of a few crucial tenets of Christianity including the cult of the saints, and the key role of the sacraments marking the rites of passage, all of which exist along with the belief in the sacredness of the earth and the spirits residing in specific mountains. These are, in Marzal's view, manifestations of an older religion that do not undermine the fact that Andean peasants are truly Christian.

The idea of syncretism to conceptualize popular Christianity is still widely accepted, although it is problematic. That two different religions could coexist intertwined whilst surviving unchanged implies the proposition that one of these religions or both can live outside from, or untouched by, history. In Marzal's own words, customs that did not correspond to the Christian tradition were 
'remains' of a long gone past. Although Marzal thought that the doctrinal faults found in popular Catholicism were to a great extent due to a dearth of able pastoral agents, an assertion that leaves the 'remains' unexplained, others within and outside academia argued that resistance accounted for them: a sustained, long term action of the oppressed could manage to eschew the grip of history altogether. ${ }^{13}$ This stance has gained wide appeal because of reasons stated at the start of this essay: the urge to condemn Spanish colonialism, the need to seek for simple, straightforward answers to complex questions about the inequalities and injustices of the present. The idealized world preceding Spanish rule was no doubt smashed into pieces, as Nathan Wachtel argued in a widely acclaimed book. Through resistance, these pieces survived unchanged throughout centuries. $^{14}$

Syncretism and resistance are strongly related to each other and have important consequences on the understanding of conversion. The two imply actions, ideas and whole sections of the human experience that can break out from history. Recurrent concerns over identity in the Andes-in fact, the world over - look not only for what is specific or 'unique' in a given culture, but reveal a proclivity to assume that such uniqueness must also be timeless. Either through the amiable path of syncretism or by way of heroic resistance, the assumption that Christianity could not admit change, or that Andean religions existing before the arrival of the Spaniards could, through the determination of those who opposed colonialism, be sealed off from foreign influences, is clearly ahistorical. Yet, political circumstances have allowed these assumptions to subsist. Seen from this perspective, conversion would involve a thorough understanding and acceptance of Catholicism, coupled with the renunciation of all previous unfitting ideas and practices. Any evidence of the latter would suggest the presence of unpolluted, ahistorical 'pagan' remains, testimony of incomplete or defective conversion.

Within the past fifteen to twenty years appeared critical views of, and alternatives to exit from, the resistance/syncretism binary. The late Henrique Urbano authored polemical pieces, pointing to the analytical and methodological problems involved in the lack of conceptual rigor and the withdrawal from historical analysis. ${ }^{15} \mathrm{His}$ articles usually attracted interest within academia, but perhaps because of Urbano's vitriolic style never elicited written replies and thus no actual debate on the subject ever took place.

In the early 1990s Sabine MacComarck's study explored the missionaries' intellectual world to comprehend how the Spanish perceived Andean religion. ${ }^{16}$ She offered a thorough examination of Inca religion, placing greater attention to its ritual life. Although acclaimed in academic journals, the book was perhaps not that widely read. The study did not reach non-English-speaking audiences. MacCormack's preoccupation with missionary methods and their philosophical background was better known through an article published in 1985, which discusses debates over conversion as a dilemma between force and persuasion. This piece is somewhat dated today, but teachers of Latin American history in the English-speaking world would agree that it still is quite useful in the classroom. ${ }^{17}$

\section{Conversion as a multiple and complex transformation}

Against the idea of resistance as the key to Andean cultural survival, Kenneth Mills argued that it was instead Andean capacity to change that allowed its endurance. ${ }^{18}$ Mills used the records produced during Church-led repressive campaigns in the Lima diocese during the seventeenth and eighteenth centuries. Taking distance from then prevailing ideas that understood religion as a cultural system, and from syncretism, Mills offered a detailed study of several components of Andean religious practices coupled with an investigation into Church agents and politics. $\mathrm{He}$ argued that ecclesiastical policies towards indigenous rural population were non-linear and showed the many forms in which Andeans engaged in their daily life with the symbols, ideas and rituals of Catholicism. This book has had a great impact on the English-speaking academia, but it has not been translated into Spanish and has not had a similar effect among Andean scholars. In this study, neither religion nor the Catholic Church are seen as uniform and impenetrable. Conversion 
occurred at the center and in the interstices of society and did not proceed regularly or predictably. Andean converts were ready to grasp and put into use what they saw fit to accommodate their spiritual and everyday needs. As this study focuses on a demarcated area, it is worth asking how far its evidence and conclusions can be applied to the whole Andean region. Also, is idolatry the only window into the history of conversion? ${ }^{19}$

In a deeply researched book, Juan Carlos Estenssoro throws his net wide and approaches conversion as the process of incorporation of indigenous Andeans to Catholicism. ${ }^{20} \mathrm{His}$ take on the subject is much more complex than the idea of 'incorporation' would initially evoke and certainly different from the 'incorporation' thought by historians in the 1950s and 1960s. Covering a period that includes the early years of Spanish presence up to the mid-eighteenth century, the study offers a thorough discussion of strategies devised for the dissemination of Christianity in the Andes, and examines key angles of their reception. Estenssoro argues against syncretism and all associated interpretations aiming at reifying religion. The author focuses on the message, its contents and varying forms and transformations, involving words, images and metaphors, dreams and historical accounts, rituals, and music. Conversion is multidimensional and, above all, a cultural transformation with significant political overtones, as Estenssoro finds in the policies aiming at incorporation a parallel process of social and political exclusion.

In a colonial setting, conversion and translation are closely intertwined. Thus the question about how Christianity was interpreted among Andeans through words and images is the most vigorously pursued in recent studies on religious change. From the perspective of linguistics, Alan Durston, César Itier, Bruce Mannheim and Gerald Taylor have produced groundbreaking analysis of literature written in Quechua, in the form of sermons, oral traditions, prayers and songs, correspondence, and drama, revealing rich dynamics of adaptation, easier to detect from the missionary side. ${ }^{21}$ The pioneering work by Monica Barnes ${ }^{22}$ and Martine Azoulai ${ }^{23}$ on catechisms and on the sacrament of penance has been continued by the recent publication of Regina Harrison's study on confession, a work with the potential to help us understand changes in the difficult terrain of emotions and sexuality. ${ }^{24}$ In the area of art and image production, to the early contributions by Teresa Gisbert and José de Mesa, ${ }^{25}$ the work by Gabriela Siracusano, ${ }^{26}$ Tom Cummins, ${ }^{27}$ Ramón Mujica Pinilla, ${ }^{28}$ and Maya Stanfield-Mazzi ${ }^{29}$ suggest that the production of images in religious conversion is perhaps the most fertile field Andean scholars can exploit. Within the vast and intricate area of the production of visual and spoken messages, the problem of how to conceptualize conversion has not yet been dealt with by most authors, especially those studying art. For example, the idea of syncretism is still uncritically used by some or never explicated, something that allows for a loose use of archival sources and a non-rigorous attention to chronology noticeable in a few works. Some of the most interesting contributions in the field of art history highlight the degree to which European images - verbal and visual-have influenced Andean religious art.

Closely related, although from a social science viewpoint, approaches to conversion as worldbuilding ${ }^{30}$ search for the impact of Christianity on the social fabric. Gabriela Ramos' study on death in the early colonial period argues that conversion had an all-encompassing transformative effect on Andean society because of the changes brought to ideas about the body and the person, on the use of space and on social relations and ritual. ${ }^{31}$ Studies focusing on specific aspects of conversion can widen our understanding of its transformative power. Recent research on confraternities, health, education and the use of the law and litigation can open up new windows not only into the religious history of the Andes but also into the shaping of society as a consequence of the insertion of, or better, encroachment of Christianity in everyday life.

\section{Conclusion}

Elucidating our conceptual understanding of conversion can lead us to discover the many layers, directions and rhythms implied in this important historical process. The political implications of conversion can be better determined and oversimplifications avoided if we are prepared to deal 
with the complexities of history. However, in the Andean region as well as in other parts of Latin America, historical understanding and political activism are often at odds. The persistence of conditions such as the spoliation of natural resources, poverty, and social and cultural discrimination often lead many to the conclusion that the region continues living in the same conditions as hundreds of years ago. Also, although much has been accomplished in the field of historical research over the past two decades, the viewpoints dominating in the 1950s and 60s are not entirely canceled, as today we witness the revival of Catholic conservatism in politics and in historical writing. ${ }^{32}$ This is yet another sign of the difficulties surrounding the study of religious change and the comprehension of its significance. 
${ }^{1}$ See Sherry Ortner's critical assessment in her 'Resistance and the Problem of Ethnographic Refusal.' Comparative Studies in Society and History. 37/1 (1995): 173-193.

${ }^{2}$ Katharine Gerbner, 'Theorizing Conversion: Christianity, Colonization, and Consciousness in the Early Modern Atlantic World'. History Compass 13/3 (2015):137-147.

${ }^{3}$ The nineteenth century saw a surge of research, editions and publication of historical documents in Spain and to a lesser degree in former Spanish colonies, like Mexico. Some of these collections aimed to document the history of Spain and its colonial possessions overseas. See for example, Colección de documentos inéditos relativos al descubrimiento, conquista y organización de las antiguas posesiones españolas de América y Oceanía, Madrid: M.B. de Quirós, 1864-1884, 42 vols, Colección de libros y documentos referentes a la historia de América. Madrid: V. Suárez 1904, 21 vols. From the early twentieth century, South American historians researching in Spanish archives, particularly in the Archivo de Indias in Seville, published collections of documents selected with a national history view in mind. Roberto Levillier, Organización de la Iglesia y órdenes religiosas en el virreinato del Perú en el siglo XVI. Documentos del Archivo de Indias. Madrid: Rivadeneyra, 1919, 2 vols., and Emilio Lissón y Cháves, La Iglesia de España en el Perú. Colección de documentos para la historia de la Iglesia en el Perú, que se encuentran en varios archivos. Seville: Católica Española, 1943.

${ }^{4}$ Written by the most representative ecclesiastical historian, Rubén Vargas Ugarte, this work was published in 1953. Vargas also published a widely used edition of the records of the Lima Church Councils titled Concilios Limenses. A modern edition of the records corresponding to the Lima Third Council was published by Francisco Leonardo Lisi in 1990: El tercer concilio limense y la aculturación de los indígenas sudamericanos : estudio crítico con edición, traducción y comentario de las actas del Concilio Provincial celebrado en Lima entre 1582 y 1583. Salamanca: Universidad de Salamanca, 1990.

${ }^{5}$ Fernando de Armas Medina, Cristianización del Perú (1532-1600). Seville: Escuela de Estudios Hispanoamericanos, 1953.

${ }^{6}$ General Francisco Franco presided over a right-wing, nationalist and profoundly Catholic dictatorship that took power after a civil war and ruled Spain from 1939 to 1975. This regime deeply influenced Spanish American culture as well as generations of historians at both sides of the Atlantic.

${ }^{7}$ Pedro Borges, OFM, Métodos misionales en la cristianización de América, siglo XVI. Madrid: Consejo Superior de Investigaciones Científicas, 1960.

${ }^{8}$ Pierre Duviols, La lutte contre les religions autochtones dans le Pérou colonial: L'Extirpation de l'idolatrie entre 1532 et 1660. Lima: Institut Français d'Études Andines, 1971. A Spanish translation was published a few years later in Mexico under the title La destrucción de las religiones (durante la conquista y la colonia), translated by Albor Maruenda. Mexico: Universidad Nacional Autónoma de México, 1977.

${ }^{9}$ See also the collections of documents this author published in two different editions: Cultura andina y represión. Procesos y visitas de idolatrías y hechicerías, Cajatambo, siglo XVII. Cuzco: Centro de Estudios Rurales Andinos Bartolomé de las Casas, 1986, and Procesos y visitas de idolatrías. Cajatambo, siglo XVII con documentos anexos. Lima: Instituto Francés de Estudios Andinos, Pontificia Universidad Católica del Perú, 2003.

${ }^{10}$ Duviols' friendship with Peruvian writer José María Arguedas in the years preceding the publication of La lutte... involved his participation in an edition of the Huarochiri manuscript, the most important written source of Andean lore originally written in Quechua. See Dioses y hombres de Huarochirí: narración quechua recogida por Francisco de Ávila. Translation by José María Arguedas, with a study of Ávila by Pierre Duviols. Lima: Museo Nacional de Historia and Instituto de Estudios Peruanos, 1966. For Duviols' and Arguedas' collaboration in the 1960s, see María del Carmen Pinilla, ed. Itinerarios epistolares. La amistad de José María Arguedas y Pierre Duviols en dieciséis cartas. Lima: Pontificia Universidad Católica del Perú, 2011. 
${ }^{11}$ Throughout the years following the publication of La lutte, Duviols has continued researching and publishing on related subjects. The argument originally presented in 1971 has evolved. Several pieces reveal the degree to which Christian ideas permeated Andean cultural manifestations. See for example Duviols' studies on popular theater 'Las representaciones andinas de la muerte de Atahualpa: sus orígenes culturales y sus fuentes.' In: Karl Kohut and Sonia V. Rose, eds. La formación de la cultura virreinal. La etapa inicial. Madrid: Iberoamericana, 2000, 213-248, and on the work of Joan Santa Cruz Pachacuti Salcamaygua. Relación de antigüedades deste reyno del Piru. Estudio etnohistórico y lingüístico de Pierre Duviols y César Itier. Cuzco: Centro de Estudios Regionales Andinos Bartolomé de las Casas, 1993.

${ }^{12}$ Manuel Marzal, a Jesuit, taught anthropology at Catholic University in Peru for many years, La transformación religiosa peruana. Lima: Pontificia Universidad Católica del Perú, 1983. This and other works by Marzal were also widely read by men and women involved in pastoral activities.

${ }^{13}$ Historians and anthropologists working within a structuralist framework tended to subscribe a static view of history even within powerful change. See for instance Nathan Wachtel, La vision des vaincus : les indiens du Pérou devant la Conquête espagnole 1530-1570. Paris: Gallimard, 1971. From a Marxist point of view, more deeply researched although with a similar approach, see Steve J. Stern, Peru's Indian Peoples and the Challenge of Spanish Conquest: Huamanga to 1640. Madison: University of Wisconsin Press, 1982.

${ }^{14}$ One of the most well-known examples of how the idea of resistance has operated and continues to operate as a denial of historical analysis and method is the episode in Peru's early colonial history known as Taqui Onqoy. An alleged widespread rebellion against Spanish presence in the Andes, the leaders of TO called for the rejection of all things Spanish and announced the return of the huacas or sacred beings that would avenge the offences and destruction the Spanish had inflicted on Andean people. A good review of the authors and issues involved in this discussion was published by Jeremy Mumford, 'The Taki Onqoy and the Andean Nation: Sources and Interpretations.' Latin American Research Review, 33 (1998): 150-165. Other articles have appeared after the publication of Mumford's piece, without adding much to the issues he pointed to.

${ }^{15}$ See for example Henrique Urbano, 'Representaciones colectivas y arqueología mental en los Andes', Allpanchis 20 (1982), 33-83, and 'Introducción' to Henrique Urbano, ed. Mito y simbolismo en los Andes: La figura y la palabra. Cuzco: Centro de Estudios Regionales Andinos Bartolomé de las Casas, 1993.

${ }^{16}$ Sabine MacCormack, Religion in the Andes: Vision and Imagination in Early Colonial Peru. Princeton: Princeton University Press, 1991.

${ }^{17}$ Sabine MacCormack, 'The Heart Has Its Reasons': Predicaments of Missionary Christianity in Early Colonial Peru'. The Hispanic American Historical Review, 65/3 (1985); 443-466.

${ }^{18}$ Kenneth Mills, Idolatry and Its Enemies: Colonial Andean Religion and Extirpation, 1640-1750. Princeton: Princeton University Press, 1997.

${ }^{19}$ The idea of idolatry extirpation as the method of evangelization is appealing. Even during the time when the Church carried out these campaigns, clergymen established in other parts of the Andes voiced their eagerness to lead extirpation activities, but were not successful.

20 Juan Carlos Estenssoro Fuchs, Del paganismo a la santidad. La incorporación de los indios del Perú al catolicismo, 1532-1750. Lima: Instituto Riva Agüero and Instituto Francés de Estudios Andinos, 2003.

${ }^{21}$ Alan Durston, Pastoral Quechua: The HIstory of Christian Translation in Peru, 1550-1650. Notre Dame: University of Notre Dame Press, 2007.

${ }^{22}$ Monica Barnes, 'Catechisms and Confesionarios: Distorting Mirrors of Andean Societies. In: Andean Cosmologies Through Time: Persistence and Emergence, edited by R.V.H. Dover, K.E. Seibold, and J. McDowell. Bloomington: University of Indiana Press, 1992.

${ }^{23}$ Martine Azoulai, Les péchés du Nouveau Monde. Les manuels de confession des Indiens XVleXVIle siècles. Paris: Albin Michel, 1993.

${ }^{24}$ Regina Harrison, Sin and Confession in Colonial Peru: Spanish-Quechua Penitential Texts, 1560-1650. Austin: University of Texas Press, 2014. 
${ }^{25}$ Teresa Gisbert and José de Mesa, Historia de la pintura cusqueña. Lima: Fundación Augusto N. Wiesse, 1982, 2 vols; Teresa Gisbert, Iconografía y mitos indígenas en el arte. La Paz: Editorial Gisbert y Compañía, 1994.

${ }^{26}$ Gabriela Siracusano, ed. La paleta del espanto: Color y cultura en los cielos e infiernos de la pintura colonial andina. Buenos Aires: Universidad Nacional de General San Martín, 2010.

${ }^{27}$ Cummins, Tom. 'Representation in the Sixteenth Century and the Colonial Image of the Inca. In: Writing Without Words, edited by Elizabeth H. Boone. Durham, N.C.: Duke University Press, 1994. ${ }^{28}$ Mujica Pinilla, Ramón, ed. El barroco peruano. Lima: Banco de Crédito, 2002 (vol. 1) and 2003 (vol.2).

${ }^{29}$ Maya Stanfield-Mazzi, Object and Apparition: Envisioning the Christian Divine in the Colonial Andes. Tucson: University of Arizona Press, 2013.

${ }^{30}$ On conversion as world-building, see Robert Hefner, 'World Building and the Rationality of Conversion,' in: Robert W. Hefner, ed. Conversion to Christianity: Historical and Anthropological Perspectives on a Great Transformation. Berkeley: University of California Press, 1993.

${ }^{31}$ Gabriela Ramos, Death and Conversion in the Andes. Lima and Cuzco, 1532-1670. Notre Dame: University of Notre Dame Press, 2010.

${ }^{32}$ Scholars of this tendency are keen in denying that there was such thing as Spanish colonialism. Most of them have chosen religious and ecclesiastical history as their preferred field of study. 